\title{
PENERAPAN PERMAINAN KASVO UNTUK MENINGKATKAN MOTIVASI PEMBELAJARAN BOLA VOLI PADA SISWA KELAS IV SDN 18 TANJUNG SARI
}

\author{
Mariana $^{1}$, Kurnia Dyah Anggorowati ${ }^{2}$, Suyatmin ${ }^{3,}$ \\ ${ }^{1}$ Mahasiswa Program Studi Penjaskesrek \\ ${ }^{2,3}$ Dosen STKIP Melawi \\ Jl. RSUD Melawi km. 04 Kec.Nanga Pinoh Kab. Melawi Kalimantan Barat \\ kurniadyah12@yahoo.com, suyatminuny@gmail.com
}

\begin{abstract}
Abstrak: This study aims to improve students' motivation and learning gains in conducting learning the volley ball through the application of game KASVO in class IV SDN 18 KKLK Tanjung Sari Nanga Pinoh.Method in a study should be right or lead to the research objectives and can be scientifically accounted results ar a expeted. The method used in this research is a class act.Based on the results of the research after the act of classed,the data showed that the acquisition of the percentage of learning motivation of fourtg grade students in class IV SDN 18 KKLK Tanjung Sari on the 1 st cycle by $45 \%$, success rate including less, are includedin the qualification success rate is quite good. The precentage of motivation for your teen to lear the fourth grade studentd in class IV SDN 18 KKLK Tanjung Sari on the second cycle of $85 \%$ is included in the qualification success rate"good" It can be conclude that the implementation of the game kasvo to improve the motivation to learn of students in learning volleyball on the students of class IV SDN 18 KKLK Tanjung Sari Nanga Pinoh said increasing
\end{abstract}

Key words: Student Motivation, Game KASVO, Learning Volley Ball.

\begin{abstract}
Abstrak: Tujuan penelitian ini adalah untuk mengetahui peningkatan motivasi belajar siswa serta perolehan hasil belajar siswa dalam permainan bola voli dengan penerapan permainan KASVO pada siswa kelas IV SDN 18 KKLK Tanjung Sari Nanga Pinoh. Metode dalam suatu penelitian harus tepat atau mengarah pada tujuan penelitian serta dapat dipertanggung jawabkan secara ilmiah sesuai dengan aturan yang berlaku, agar dalam penelitian tersebut dapat diperoleh hasil yang sesuai dengan yang diharapkan. Metode penelitian yang digunakan dalam penelitian ini adalah penelitian tindakan kelas. Berdasarkan hasil dari penelitian setelah dilakukan tindakan kelas, data menunjukanbahwaperolehanPresentase Motivasi belajar siswa kelas IV SDN 18 KKLK Tanjung Sari pada siklus I sebesar $45 \%$ tingkat kebehasilan termasuk kurang, termasuk dalam kualifikasi tingkat keberhasilan" cukup baik" .Presentase Motivasi belajar siswa kelas IV SDN 18 KKLK Tanjung Sari pada siklus II sebesar 85\% termasuk dalam kualifikasi tingkat keberhasilan "baik" Dengan demikaian dapat disimpulkan bahawa penerapan permainan KASVO untuk meningkatkan motivasi belajar siswa dalam pembelajaran bola voli
\end{abstract}


pada siswa kelas iv SDN 18 KKLK Tanjung Sari Nanga Pinoh dikatakan berhasil.

Kata Kunci: Motivasi Siswa, Permainan KASVO, Pembelajaran bola voli.

$\mathrm{B}$ erdasarkan hasil observasi peneliti di SDN 18 KKLK Tanjung Sari, pada siswa kelas IV. Banyak sekali pengalaman yang peneliti peroleh dari kegiatan tersebut, baik pada saat proses pembelajaran pendidikkan jasmani olahraga dan kesehatan khusus mata pelajaran bola voli berlangsung, yaitu: masih kurangnya siswa yang gemar dengan olahraga bola voli data ini diperoleh data kuisioner yang dikumpulkan dari siswa, kurangnya semangat belajar siswa dilihat dari tidak adanya siswa yang aktif bertanya dalam proses pembelajaran, siswa yang ribut, acuh tak acuh, siswa sering keluar masuk kelas ketika jam pelajaran, rendahnya pemahaman siswa tentang permainan bola voli, proses pembelajaran atau metode yang digunakan oleh guru kurang bervariasi, permainan kasvo belum pernah diterapkan

Melihat masalah tersebut, maka perlu diterapkan suatu sistem pembelajaran yang melibatkan peran siswa secara aktif dalam kegiatan belajar mengajar guna menumbuhkan motivasi belajar siswa. Motivasi belajar adalah keseluruhan daya penggerak baik dari dalam diri maupun dari luar siswa (dengan menciptakan serangkaian usaha untuk menyediakan kondisi-kondisi tertentu) yang menjamin kelangsungan dan memberikan arah pada kegiatan belajar, sehingga tujuan yang dikehendaki dapat tercapai.Motivasi belajar diperlukan oleh seorang siswa dalam mempelajari suatu materi atau pokok

Kasvo merupakan salah satu bentuk modifikasi pembelajaran bola voli yang dikemas dalam sebuah permainan kasti yang dimodifikasi. Sesuai dengan namanya kasvo merupakan perpaduan dari dua kata yakni kasti dan voli, berbeda dengan permainan kasti pada umumnya permainan kasvo tidak menggunakan pemukul dan bola kasti namun menggunakan bola spons atau bola voli. Tujuan permainan kasvo ini adalah untuk membuat pembelajaran servis bawah bola voli menjadi sebuah permainan kompetisi yang menyenangkan namun tetap sesuai dengan tujuan gerak dasar yang ingin dicapai, Sehingga siswa terbiasa 
melakukan servis bawah tanpa tertekan oleh tuntutan harus melewati net atau masuk kelapangan seperti pada permainan bola voli pada umumnya.

Motiv dapat diartikan sebagai suatu kondisi internal (kesiapan, dan kesiagaan), yang berawal dari kata "motiv" itu, maka motivasi dapat diartikan sebagai daya penggerak yang telah aktif pada saat-saat tertentu terutama apabila kebutuhan untuk mencapai tujuan sangat dirasakan mendesak.

Soemanto (dalam Abdul Majid, 2014:307 secara umum mendefinisikan motivasi sebagai suatu perubahan tenaga yang ditandai oleh dorongan efektif dan rekreasi-rekreasi pencapaian tujuan. Akan tetapi prilaku manusia itu selalu bertujuan, karena itu dapat menyimpulkan bahwa perubahan tenaga yang memberi kekuatan bagi tingkah laku mencapai tujuan telah terjadi di dalam diri seseorang.

Menurut Uno (2015 : 23) Motivasi dan belajar merupakan dua hal yang saling mempengaruhi. Belajar adalah perubahan tingkah laku secara relatif permanen dan secara potensial terjadi sebagai hasil dari praktis atau penguatan (reinforced practice) yang dilandasi tujuan untuk mencapai tujuan
tertentu.Teori motivasi dan pengukurannya analisis dibidang pendidikan.

Belajar merupakan proses perubahan perilaku secara aktif, proses mereaksi terhadap semua situasi yang ada di sekitar individu, proses yang diarahkan kepada suatu tujuan, proses berbuat melalui berbagai pengalaman, proses melihat, mengamati, memahami sesuatu yang ingin dipelajari (Gino, dkk: 1998: 31).

Menurut reigeluth dan carr-chellman dalam Muhammad Yaumi (2013:57) pembelajaran dapat didefinisikan "as anything that is done purposely to facilitate learning, Artinya, pembelajaran dapat dipahami sebagai segala sesuatu yang dillakukan maksud untuk memfasilitasi belajar. Pembelajaran juga dipahami sebagai upaya yang disengaja untuk mengelola kejadian atau peristiwa belajar dalam memfasilitasi peserta didik sehingga memperoleh tujuan yang dipelajari.

Dari berbagai pendapat di atas dapat disimpulkan bahwa motivasi belajar adalah kesanggupan untuk melakukan kegiatan belajar karena didorong oleh keinginannya untuk memenuhi kebutuhan dari dalam dirinya ataupun yang datang dari luar. Kegiatan 
itu dilakukan dengan kesungguhan hati dan terus menerus dalam rangka mencapai tujuan.

Motivasi belajar siswa dapat dianalogikan sebagai bahan bakar untuk menggerakkan mesin motivasi belajar yang memadai yang lakan mendorong siswa berperilaku aktif untuk berprestasi dalam kelas.

\section{METODE PENELITIAN}

Penelitian ini merupakan penelitian tindakan kelas pada pendidikanjasmani. Dalam penelitian ini digunakan modifikasi permainan KASVO pada pembelajaran bola voli. Pada penelitian ini yang menjadi subjek dalam penelitian ini adalah siswa kelas IV SDN 18 KKLKTanjung Saridengan jumlah siswa 20 siswa terdiri dari 11 siswa laki-laki dan 9 siswa perempuan. Prosedur penelitian ini menggunakan metode penelitian tindakan kelas dengan model John Elliot yang meliputi perencanaan, pengamatan, pelaksanaan, dan refleksi. Teknik pengumpulan data dalam penelitian ini adalah menggunakan teknik non tes dalam bentuk lembaran observasi. Dalam penelitian ini lembaran observasi digunakan untuk melihat keterlaksanaan proses pembelajaran guru dan siswa dalam proses pembelajaran, sedangkan lembar observasi motivasi digunakan untuk mengukur motivasisiswa dalam pembelajaran bola voli dengan menggunakan permainan kasvo.

Instrumen yang digunakan untuk mengumpulkan data dalam penelitian ini terdiri dari 3 macam yaitu lembar observasi keterlaksanaan RPP, lembar angket motivasi belajar siswa dan tes hasil belajardengan kisi-kisi sebagai berikut; Lembar observasi keterlaksanaan RPP digunakan untuk mencatat semua kegiatan selama pembelajaran berlangsung, baik kegiatan guru sewaktu mengajar, maupun respon siswa sewaktu belajar dan keaktifan siswa sewaktu pembelajaran berlangsung. Angket motivasi belajar siswa digunakan untuk mengukur motivasi belajar siswa pada saat pembelajaran berlangsung dengan menggunakan permainan kasvo, ada 36 soal Angket dilampirkan,dan keterangan pilihan jawaban. Aspek -aspek yang diamati adalah :

1. Perhatian (Attention)

2. Relavansi(Relavance)

3. Percaya diri(Confidence)

4. Kepuasan(Satisfication)

Analisis data merupakan langkah penting dalam penelitian, karena merupakan upaya dalam mencari dan 
menata sistematis catatan hasil penelitian, karena dalam penelitian ini merupakan nilai dalam suatu tes dan data yang terkumpul, maka objektivitas dari hasil penelitian akan lebih terjamin. Analisis data dapat memberikan efisiensi dan efektifitas kerja karena dapat membuat data lebih ringkas bentuknya.Data yang dikumpulkan pada kegiatan observasi proses pembelajaran akan diolah sebagai berikut:

\section{Data lembar observasi}

Lembar observasi ini dibuat untuk melihat sejauh mana guru dan siswa dapat melakasanakan proses kegiatan belajar mengajar data hasil observasi keterlaksanaan RPP dengan rumus:

Persentase RPP = $\frac{\text { Jumlah Skor Perolehan Kegiatan }}{\text { Total Skor Ideal }} \times 100 \%$

Sumber : Jurnal STKIP Melawi

\section{Data angket}

Data angket dianalisis dengan perhitungan, jumlah skor yang diperoleh dibagi dengan skor total dikali seratus persen. Menghitung skor rata-rata gabungan dari kriteria positif dan negatif setiap kondisi, kemudian menentukan kategorinya dengan ketentuan skor rata-rata 1,00 -1,49 =tidak baik, 1,50 2,49 =kurang baik, 2,50 - 3,49 =cukup baik, 3,50 - 4,49 =baik, dan 4,50 - 5,00 =sangat baik.

\section{HASIL DAN PEMBAHASAN}

Deskripsi penelitian terdiri dari dua siklus secara berulang yang meliputi siklus I dan siklus II. Setiap siklus dalam penelitian ini meliputi empat tahap sebagaimana yang dikemukakan oleh Lewin dalam Kusmah \& Dwitagama (2010:20). Yaitu perencanaan (planning), pelaksanaan (acting), pengamatan (observing), dan refleksi (reflecting). Setelah peneliti melakukan prosedur Penelitian Tindakan Kelas (PTK), maka diperoleh hasil penelitian yang terbagi ke dalam dua siklus, yaitu siklus I dan siklus II. Hasil kedua siklus akan dijelaskan sebagai berikut.

\section{Hasil Tindakan Siklus I dan Siklus II}

Siklus I mencakup dua kali pertemuan, pertemuan pertama mulai dilaksanakan pada hari selasa tanggal 5 April 2017, dan pertemuan kedua dilaksanakan pada tanggal 12 April 2017, yang dihadiri oleh 20 orang siswa, satu orang observer yakni guru PENJASKES kelas IV di sekolah tersebut dan satu orang dokumenter yakni teman sejawat peneliti

Siklus II mencakup dua kali pertemuan, pertemuan pertama mulai dilaksanakan pada hari selasa tanggal 19 April 2017, dan pertemuan kedua dilaksanakan pada tanggal 26 April 
2017, yang dihadiri oleh 20 orang siswa, satu orang observer yakni guru PENJASKES kelas IV di sekolah tersebut dan satu orang dokumenter yakni teman sejawat peneliti.

Hasil perolehan persentase keterlaksanaan pembelajaran siklus I pada kegiatan awal pertemuan pertama memperoleh persentase $40 \%$ kemudian pada pertemuan kedua memperoleh persentase $60 \%$ dengan rata-rata persentase kegiatan awal 50\%. Kegiatan inti pertemuan pertama memperoleh persentase $50 \%$ pada pertemuan kedua memperoleh persentase $66,66 \%$, dengan rata-rata persentase kegiatan inti $58,33 \%$. Kegiatan akhir pertemuan pertama memperoleh persentase $50 \%$ pada pertemuan kedua memperoleh persentase $75 \%$, dengan rata-rata persentase kegiatan akhir 62,5\%. Jumlah rata-rata yang diperoleh pada siklus I adalah 56,94\%.

Hasil persentase keterlaksanaan pembelajaran siklus II pada kegiatan awal pertemuan pertama memperoleh persentase $80 \%$ kemudian pada pertemuan kedua memperoleh persentase $100 \%$ dengan rata-rata persentase kegiatan awal 90\%. Kegiatan inti pertemuan pertama memperoleh persentase $83,33 \%$ pada pertemuan kedua memperoleh persentase $100 \%$, dengan rata-rata persentase kegiatan inti 91,66\%. Kegiatan akhir pertemuan pertama memperoleh persentase $75 \%$ pada pertemuan kedua memperoleh persentase $100 \%$, dengan rata-rata persentase kegiatan akhir 87,5\%. Jumlah rata-rata yang diperoleh pada siklus I adalah $89,72 \%$.

Perolehan motivasi belajar pada permainan bola voli dengan menggunakan permainan kasvo pada siklus I adalah $45 \%$ dari 20 siswa tuntas dan $55 \%$ dari 20 siswa tidak tuntas. Dengan nilai rata-rata dari setiap aspek antara lain : Dengan jumlah perolehan rata-rata aspek perhatian dari 20 siswa 69,8 jadi rata-rata 3,49, jumlah perolehan rata-rata relevansi dari 20 siswa 68,6 jadi rata-rata 3,43 jumlah perolehan rata-rata aspek Percaya diri 20 siswa 703 jadi rata-rata 3,50 dan jumlah perolehan rata-rata aspek dari 20 siswa 69,6 Kepuasan 3,48 Dengan demikian perolehan motivasi belajar siklus I dikatakan belum berhasil.

Sedangkan pada siklus II adalah $85 \%$ dari 20 siswa tuntas dan $15 \%$ dari 20 siswa tidak tuntas. Dengan nilai rata-rata dari setiap aspek antara lain : Dengan jumlah perolehan rata-rata aspek perhatian dari 20 siswa 82,2 
jadi rata-rata 4,11 jumlah perolehan rata-rata relevansi dari 20 siswa 82,8 jadi rata-rata 4,14 jumlah perolehan rata-rata aspek Percaya diri 20 siswa 82,2 jadi rata-rata 4,11 dan jumlah perolehan rata-rata aspek dari 20 siswa Kepuasan 81,8 jadi rata-rata 4,09 Dengan demikian perolehan motivasi belajar pada siklus II dikatakan berhasil.

Perolehan hasil belajar dari jumlah siswa sebanyak 20 0rang dengan presentase ketuntasan $20 \%$ dan tidak tuntas $80 \%$. Perolehan hasil belajar dengan nilai tertinggi 88,14 dan terendah 51,85. Jumlah nilai keseluruhan 1296 dikalikan 100 kemudian dibagi 20 orang maka nilai rata-rata adalah 64,8 Dengan demikian rata rata perolehan hasil belajar siswa pada pembelajaran bola voli pada siklus I dapat disimpulkan bahwa penelitian pada siklus I belum berhasil dan akan dilanjutkan ke siklus ke II.

Perolehan hasil belajar siswa pada siklus II bahwa pembelajaraan bola voli dari jumlah siswa sebanyak 20 siswa dengan persentase ketuntasan 17 siswa atau $85 \%$ dan tidak tuntas sebanyak 3 siswa atau $15 \%$. Nilai pembelajaraan bola voli siswa yang paling tertinggi adalah 91,1 dan yang terendah adalah 57,22 . Jumlah nilai siswa keseluruhannya 1546,43 dibagi 20 Orang maka nilai rata-rata adalah 81,87 . Dengan demikian rata-rata pembelajaran bola voli pada siklus II dikatakan berhasil. Maka dapat disimpulkn bahwa penelitian ini berhenti sampai disiklus II dikarenakan sudah berhasil.

Hasil presentase perolehan hasil belajar bahwa pembelajaraan bola voli dari jumlah siswa sebanyak 20 siswa dengan persentase ketuntasan 17 siswa atau $85 \%$ dan tidak tuntas sebanyak 3 siswa atau $15 \%$. Nilai pembelajaraan bola voli siswa yang paling tertinggi adalah 91,1 dan yang terendah adalah 57,22. Jumlah nilai siswa keseluruhannya 1546,43 dibagi 20 Orang maka nilai rata-rata adalah 81,87 . Dengan demikian rata-rata pembelajaran bola voli pada siklus II dikatakan Dengan demikan dapat disimpulkan dengan meningkat nya motivasi belajar juga dapat mempengaruhi perolehan hasil belajar siswa. Berdasarkan hasil PTK yang peneliti lakukan dari siklus I sampai siklus II, peneliti dapat menyimpulkan bahwa dengan menerapkan permainan KASVO dalam pembelajaran bola voli motivasi siswa dalam kegiatan belajar 
mengajar, hasil belajar dan motivasi belajar telah meningkat .

Berdasarkan hasil penelitian yang telah peneliti lakukan, peneliti dapat menyimpulkan bahwa dengan bantuan penerapan permainan kasvo dalam mengajarkan teknik dasar service bawah bola voli pada mata pelajaran pendidikan jasmani dan kesehatan terhadap motivasi belajar siswa dan hasil belajar siswa semakin meningkat. Hasil pengamatan terhadap proses pembelajaran mulai dari, Siklus I, dan Siklus II ini adalah sebagai berikut :

\section{SIMPULAN}

Berdasarkan analisis terhadap data hasil penelitian tindakan kelas ini, dapat disimpulkan bahwa penerapan permainan KASVO dapat meningkatkan motivasi pembelajaranbola volidikelas IV SDN 18 KKLK Tanjung Sari Nanga Pinoh tahun pelajaran 2016/2017 pada semester genap. Peningkatan motivasi dalam proses pembelajaran bola voli menggunakan permainan KASVO terlihat dari hal-hal berikut:

Presentase Motivasi belajar siswa kelas IV SDN 18 KKLK Tanjung Sari pada siklus I sebesar $45 \%$ tingkat kebehasilan termasuk kurang. Termasuk dalam kualifikasi tingkat keberhasilan cukup
Presentase Motivasi belajar siswa kelas IV SDN 18 KKLK Tanjung Sari pada siklus II sebesar 85\% Termasuk dalam kualifikasi tingkat keberhasilan "baik"

Dengan meningkatnya motivasi belajar siswa dapat dikatakan proses hasil belajar siswa juga meningkat karena dengan meningkatnya motivasi

Dengan meningkatnya motivasi belajar siswa dapat dikatakan proses hasil belajar siswa juga meningkat karena dengan meningkatnya motivasi belajar siswa juga berpengaruh terhadap hasil belajar siswa

Dengan demikian dapat disimpulkan bahwa penerapan permainan kasvo dapat meningkatkan motivasi pembelajaran bola voli pada siswa kelas IV SDN 18 KKLK Tanjung Sari dikatakan berhasil.

\section{DAFTAR PUSTAKA}

Jurnal STKIP Melawi. 2014. Pendididkan Jasmani Kesehatan dan Rekreasi. Melawi: STKIP Melawi

Mahmud. 2001. Metode Penelitian Pendidikkan. Bandung: Pustaka Setia.

Majid, A. 2014. Strategi Pembelajaran. Bandung: PT Remaja Rosdakarya. 
Uno, H. B. 2015. Teori Motivasi Dan Pengukurannya. Bandung: PT Bumi Aksara.

Yaumi, M. 2013. Prinsip-Prinsip Desain Pembelajaran. Jakarta:

Kencana Prenada Media Group. 